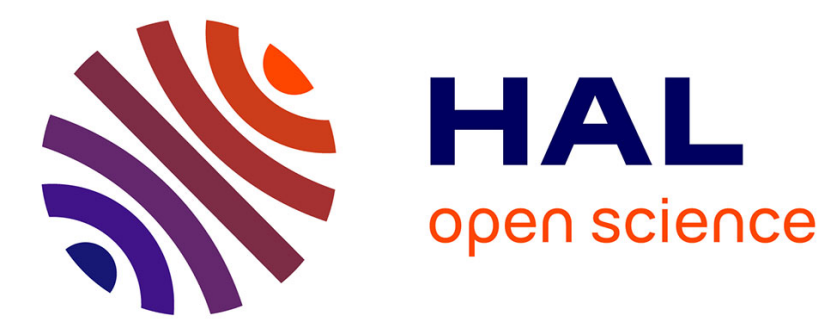

\title{
Spanish Bare Plurals and Topicalization
}

Brenda Laca

\section{To cite this version:}

Brenda Laca. Spanish Bare Plurals and Topicalization. International Workshop on Sentence-Initial Bare Nouns, Jun 2011, Tübingen, Germany. hal-00773224

\section{HAL Id: hal-00773224 https://hal.science/hal-00773224}

Submitted on 12 Jan 2013

HAL is a multi-disciplinary open access archive for the deposit and dissemination of scientific research documents, whether they are published or not. The documents may come from teaching and research institutions in France or abroad, or from public or private research centers.
L'archive ouverte pluridisciplinaire HAL, est destinée au dépôt et à la diffusion de documents scientifiques de niveau recherche, publiés ou non, émanant des établissements d'enseignement et de recherche français ou étrangers, des laboratoires publics ou privés. 
Brenda Laca

Université Paris 8 - CNRS UMR7023

\section{Spanish Bare Plurals and Topicalization* Abstract}

Taking issue with the unsatisfactory aspects of the "ambiguity" approach to BPLs, Dobrovie-Sorin \& Laca $(1996,1998,2003)$ endeavoured to develop an account that could recover Carlson's (1977) original insight as to the semantic uniformity of English BPLs, while at the same time doing justice to the behavior of BPLs in Spanish-like languages. In this account, BPLs are basically $<\mathrm{e}, \mathrm{t}>$-type expressions that denote plural properties. Subsequent work by Cohen and Erteschick-Shir (Cohen \& Erteshick-Shir 2002 , Cohen 2007, 2009) has provided formally explicit answers to many of the questions left open by Dobrovie-Sorin \& Laca. However, the hypothesis they formulate, according to which Topics may not be incorporated, so that BPL-Topics may only compose via "covert nominalization", meets a serious problem: Spanish exhibits apparently "topicalized" BPLs. This paper addresses the problem of "topicalized" BPls, which appear at the left edge of the clause and are excluded from clauses with a reduced CP-structure. We sketch an analysis in which the type-shifting operation on the verb required for the existential import of such structures is triggered by a null propertydenoting nominal, whose existence in Spanish is independently suggested by cases of indefinite argument drop and by NPs/DPs lacking a nominal head.

\section{Introduction}

The basic distribution fact about Spanish BPLs is still best summarized in the constraint formulated by Suñer (1982: 209) as the Naked-Noun Constraint:

An unmodified common noun in the preverbal position cannot be the surface subject of a sentence under conditions of normal stress and intonation.

This constraint is illustrated by the contrast between (1a) and (1b):
a. Asistieron obispos.
PostVerbal SUBJECT attended $3 \mathrm{pL}$ bishops
'(Sm) bishops attended'
b. *Obispos asistieron.
bishops attended $3 \mathrm{PL}$
PReverbal SUbJect

As stated in the formulation of the Naked-Noun Constraint, special intonational contours may rescue the offending sequence (1b).
a. OBISPOS asistieron.
bishops attended 3 PL
'(Even some) bishops attended'

EMPH-FOCUS-FRONTING

\footnotetext{
* Thanks to the audiences at the Tübingen Meeting on Sentence-Initial Bare Nouns and at the $3^{\text {rd }}$ Conference on Bare Nouns (Rio de Janeiro), in particular to Susan Rothstein. Thanks also, as always, to Patricia Cabredo-Hofherr and Jean Lowenstamm. I'm particularly grateful to the two anonymous reviewers for their insightful suggestions, which I have endeavoured to integrate in the final version of this paper.
} 
b. Obispos asistieron

bishops attended $3 \mathrm{PL}$

'Topicalization'

'(As for) bishops, (some) attended'

[pero no arzobispos/ pero se retiraron de inmediato]

[but no archbishops did/ but they left rightaway]

(2a) is a straightforward case of emphatic Focus-fronting: the most prominent pitch in the sequence is assigned to the preverbal constituent, and the rest of the sequence is deaccented. By contrast, the intonational contour of $(2 \mathrm{~b})$-as required by the proposed continuations- is more difficult to describe. It contrasts with the pattern in (2a) because in this case the verb is not deaccented, but it also contrasts with the "unmarked" pattern (1b) in a way that it is less easy to pin down. The pattern contains two intonational units, with a high rise of the pitch after the stress bearing syllable of the first constituent (the "topicalized" BPL). Since this intonation pattern is exactly parallel to that of the fronted BPL object in (3a), we may conclude that the subject is not sitting in the same position in the offensive (1b) and in the fully acceptable (2b). Finally, the type of structure illustrated in (3b), in which a fronted BPL is associated to an in-situ DP lacking a head noun, is intuitively (and intonationally) similar to (2b) and (3a).
a. Bicicletas vendemos [pero en este momento no hay] bycicles sell $_{1 \mathrm{PL}}$ [but at this moment not there-is ]
'We do sell bicycles, but we have none at the moment'
b. Obispos asistieron varios.
bishops attended 3 PL several
'(As for) bishops, several attended'

SPLiT-Topicalization

'OBJ.Topicalization'

Topicalized constructions as those illustrated by (2b) and (3a-b) have received comparatively little attention. In what follows, I will first show that they pose a serious problem for the analysis of BPLs as property-denoting expressions -an analysis I still think is well motivated. On a second step, I will propose a solution for this problem that builds on a pattern of argument drop that has been little discussed up to now. ${ }^{1}$

\section{Towards a uniform approach to BPLs.}

\subsection{BPLs as property denotations.}

When describing the behaviour of Spanish BPLs along the lines traced in Carlson's monumental work on English, it soon becomes apparent that Spanish BPLs are very

\footnotetext{
1 It should be noted that the Naked-Noun Constraint is not meant to hold for modified BPLs, as illustrated by the examples below:

(i) Individuos de aspecto siniestro jugaban al billar en la trastienda.

'Sinister-looking individuals played/were playing billiards in the backroom'

(ii) Eléctricas letras verdes intermitentes anunciaron la llegada del vuelo

'Electric blinking green lights announced the flight's arrival'

[M. Vázquez Montalbán, El delantero centro fue asesinado al atardecer, 213]

I will have nothing to say about such cases, except for the fact that they belong to a circumscribed register (background descriptions in literary narratives).
} 
much like English BPLs, except for a not so minor point: Spanish BPLs are unable to denote kinds. They can be shown not to behave as referential expressions, nor as quantified expressions. Laca (1996) formulated this intuition by saying that Spanish BPLs denote "kinds of things" qua sets, i.e. as restrictors of quantification having no quantificational force of their own.

The main properties on which this statement is based are (i) their incompatibility with kind predicates, shown by examples $(4 a-b),{ }^{2}$ and (ii) the fact that they always have narrow scope with regard to other scope-bearing elements affecting the verb, such as negation in (5a), or a quantificational element in (5b):

a. En la China se están extinguiendo *(los) pandas. in the China REFL are extinguishing *(the) pandas

'In China, pandas are on the verge of extinction'

b. Aquí abundan *(los) escorpiones here abound $3 \mathrm{PL} *$ (the) scorpions. 'There are lots of scorpions here'

a. A la reunión no asistieron profesores.

to the meeting not attended 3 PL professors.

'No professors attended the meeting'

b. Con profesores me encuentro todos los miércoles.

With professors me find ${ }_{15 G}$ all the Wednesdays

'I meet with professors every Wednesday'

Moreover, the anaphoric behaviour of BPLs clearly contrasts with that of "weak indefinites" introduced by a determiner. Though frequently glossed over, these effects, which were first described for English by Carlson (1977), are particularly significant. BPLs are very natural as antecedents for type-anaphora, an anaphora that concerns type-identity and not identity of the individual tokens. Thus, (6a) is perfectly fine, whereas (6b) only has the absurd reading in which the books that get written are those that were previously burnt:

a. Porque usted quema libros y él los escribe. because you burn books and he AccCl write. 'Because you burn books, and he writes them'

\footnotetext{
2 Let me stress that the inacceptability of examples like (4a-b), together with the contrast between (i) and (ii) below, clearly weakens the explanatory power of approaches that account for the Naked Noun Constraint by assuming that BPLs are headed by a null determiner/quantifier requiring lexical government (Contreras 1996, Chierchia 1998):

(i) Estaban presentes profesores. were $_{3 \mathrm{PL}}$ present professors 'Professors were present' (ii) * Estaban enfadados profesores. were $_{3 \mathrm{PL}}$ angry professors 'Professors were angry'

There is no reason to suppose that the postverbal subject of be on the verge of extinction or abound is "less" lexically governed than that of sing or play, or that the subject of be present is "more" lexically governed than that of be angry.
} 
b. \#Porque usted quema unos/algunos libros y él los escribe. because you burn some books and he AccCl write. 'Because you burn books, and he writes them'

Secondly, BPLs can only be antecedents for other as an expression of complement anaphora if we have disjointness at the level of the descriptive content: otros 'other' in (7) can only be understood as 'other (people) who are not socialists', and not as 'other socialists':

Así como hoy encarcelaron socialistas, mañana encarcelarán a otros. so how today jailed 3 PL socialists, tomorrow will-jail ${ }_{3 \mathrm{PL}}$ to others. 'Just as they jailed socialists today, they will jail others tomorrow'

Thirdly, BPLs do not exhibit anaphoric or D-linked (partitive) readings, which renders the continuation in (8) incoherent:

(8) En la reunión había estudiantes y profesores. \#Yo ya conocía estudiantes. in the meeting had 3 SG students and professors. \#I already knew students.

'There were students and professors at the meeting. \#I had already met students'

Finally, and even more puzzlingly, BPLs allow for disjointness at the token-level even in the case of verb coordination. Thus, (9a) does not entail that any particular shirt got washed and ironed by me yesterday, and (9b) can be verified by a situation in which the famous writers born in the city and the famous writers who died in the city are different sets with a null intersection.
a. Ayer lavé y planché camisas.
yesterday washed ${ }_{1 \mathrm{SG}}$ and ironed $_{1 \mathrm{SG}}$ shirts.
'Yesterday I washed and ironed shirts'
b. En esta ciudad nacieron y murieron escritores célebres. in this city were-born and died writers famous
'Famous writers were born and died in this city'

In sum, Spanish BPLs have all the properties of the "existential" English BPLs, as described by Carlson, while being disallowed in the positions that trigger "generic" BPls.

Now, if we contend that Spanish BPLs are neither referential nor quantified expressions, and that they denote "sets as restrictors of quantification", the obvious open option is to treat them as property denotations, as expressions of type $<\mathrm{e}, \mathrm{t}>$. This is the line of thought followed by Dobrovie-Sorin \& Laca $(1996,1998,2003)$. In their account, BPLs are basically <e,t>-type expressions that denote properties of pluralities (sets of sums that are partially ordered by the part-of relation into join semi-lattices).

This is a simple hypothesis, which takes BPLs so to say at face value: BPLs lack a Det, are syntactically NPs, and have the standard semantic type for NPs. But, of course, such simplicity comes at a very high cost when you try to compose argumental BPLs with the sentential predicate, since it forces the assumption that (some) verbs admit $<\mathrm{e}, \mathrm{t}>$-type expressions in (some of) their argument positions, and that the existential force of BPLs comes from the verb. Such a mechanism, which corresponds to the semantics of incorporation (Van Geenhoven 1995, Mc Nally 1995/2004), accounts for existential BPLs and their characteristic narrow scope behavior. 
Dobrovie-Sorin \& Laca assumed that the mechanism has a lexical basis, in the sense that some verbs have an incorporating version, in which they supply an existential quantifier over a given argument position. (10a-c) give three possible lexical entries for a transitive verb:

a. non-incorporating transitive verbs: $\quad \lambda y \lambda x(x V y)$

b. Obj-incorporating transitive verbs: $\quad \lambda P \lambda x \exists y(x V y \wedge P y)$

c. Sbj-incorporating transitive verbs: $\quad \lambda y \lambda P \exists x(x \vee y \wedge P x)$

According to Dobrovie-Sorin \& Laca, the difference between English and Spanish boils down to the fact that English allows the "covert nominalization" $(<e, t>\rightarrow$ e-type shift) of BPLs. This "covert nominalization" corresponds to the effects of Chierchia's down operator in (11), a function that maps a situation (world/time) onto the largest member of the extension of the property $\mathrm{N}$ (the maximal element of the semilattice) in this situation, and is defined only if $\mathrm{N}$ is not an unordered set of singularities.

$$
{ }^{n} \mathrm{~N}=\lambda \mathrm{s} \iota \mathrm{N}_{\mathrm{s}}
$$

As exemplified in (12a-c), all generic BPls are analyzed as instances of nominalized, kind-referring BPLs, and the same analysis is extended to the 'functional' readings discussed by Condoravdi (1994) in (12d).

a. Tigers are on the verge of extinction.

KIND DENOTATION

b. Tigers are striped.

KIND DENOTATION

c. Mowgli hates tigers.

KIND DENOTATION

d. We are reaching the end of the term.

"quasi-universal" readings

Students are exhausted.

By contrast with English, Spanish-type languages do not allow "covert nominalization". This leaves incorporation as the only option for BPLs, which thus always behave as "weak" indefinites.

A number of questions were left open in this proposal:

(i) what is the relationship between "normal" (non-incorporating) and incorporating versions of a predicate?

(ii) what determines if a predicate can or cannot develop an incorporating version for a given argument position?

(iii) if "generic" readings of BPLs have a single source, namely reference to maximal entities via an $\langle$ e,t $>\rightarrow$ e type-shift, how do we account for the prominent quantificational effects that clearly arise with adverbs of quantification, and, somewhat less clearly, in habitual characterizing sentences?

(iv) why do English-like and Spanish-like languages differ in precisely the way they differ?

\subsection{BPLs and information structure.}


Work by Cohen \& Erteschick-Shir (Cohen \& Erteshick-Shir 2002, Cohen 2007, 2009) has provided formally explicit answers to questions (i) to (iii) above. I will concentrate in what follows on the answers provided to questions (i) and (ii), because, satisfactory though they are, they meet a serious difficulty with the analysis of the topicalization constructions mentioned in the introduction.

The main tenets of Cohen and Erteschick-Shir's approach can be best introduced by means of the derivation of an example sentence, such as (13) below, in which the object gets an existential, and the subject a generic interpretation:

\section{Manuscripts contain typos.}

Cohen (2009) remarks that type-shifted versions in which a predicate takes an $<e, t>$-type argument are independently needed in order to account for coordination of intensional with extensional verbs (as in John needed and bought a new coat), the former being analyzed as taking a property-type object. Existential type-shift is thus a rescue operation in the grammar which is available for the resolution of type-mismatches, such as those created by a property-type expression in argument position. As shown in (14b) and (14c), when the verb finds a BPL (an <e,t>-type expression) in an argument position, it is free to shift in order to apply to this argument:

a. contain $=\lambda \mathrm{y} \lambda \mathrm{x}(\mathrm{x}$ contain $\mathrm{y})$

b. $\lambda \mathrm{y} \lambda \mathrm{x}$ ( $\mathrm{x}$ contain $\mathrm{y})($ typos)

TYPE MISMATCH

c. SHIFT $($ contain $)=\lambda \mathrm{P} . \lambda \mathrm{x}$. $\exists \mathrm{y} \mathrm{P}(\mathrm{y}) \& \mathrm{x}$ contain $\mathrm{y}$ EXISTENTIAL TYPE-SHIFT

d. $[\lambda \mathrm{P} . \lambda \mathrm{x} . \exists \mathrm{y} \mathrm{P}(\mathrm{y}) \& \mathrm{x}$ contain $\mathrm{y}]$ (typos)

e. $\lambda \mathrm{x} . \exists \mathrm{y}$ typos $(\mathrm{y}) \&(\mathrm{x}$ contain $\mathrm{y})$

Two important features of this operation should be noticed:

(i) Type-shifting of a predicate into an "incorporating" version is triggered as a way of solving a type-mismatch. It is not an option that is lexically available for some verbs and some argument positions, as assumed in most classic incorporation accounts. This answers the question as to the relationship between "normal" and "incorporating" versions of a predicate (see question (i) above) in a very satisfactory way.

(ii) Since type-shifting is a local phenomenon, existential quantification stems from the verb at the stage of its composition with the mismatched argument. This accounts for the characteristic narrow scope of existential BPLs. A welcome consequence of this setup is that the mechanism is able to derive the special scope facts with regard to verb coordination alluded to in the introduction and exemplified by (9a-b) above. If both verbs are shifted, and each shift introduces its own existential quantifier, we get the puzzling disjoint readings of $(9 a-b)$ for free. ${ }^{3}$

In addition to the general possibility of existential type-shift of the predicate (corresponding to the "incorporation" option), English allows the "covert" $<e, t>\rightarrow \mathrm{e}$

\footnotetext{
${ }^{3}$ In the kind-analysis, this interpretation poses no problem, since the relationship of instantiations to the kind is such that no token-identity is required. By contrast, analyses introducing an existential quantifier via the BPL (and not via each verb), as in Krifka 2004, cannot obtain the reading lacking token-identity. Please notice that I'm distinguishing between genuine verb coordination and asymmetric coordination or right-node raising: in the latter, the interpretation contrast between BPL and other indefinites disappears. Genuine verb coordination is characterized by the lack of any parenthetic intonation and by a necessary "semantic frame" association between the Vs, as in wash and iron, sell and repair (see Abeillé 2006).
} 
type-shift of BPLs ("nominalization"). This is shown below for the composition of the subject BPL:
a. $[\lambda \mathrm{x} \exists \mathrm{y}$ typos $(\mathrm{y}) \&$ (x contain $\mathrm{y})]$ (manuscripts)
TYPE MISMATCH
b. $[\lambda \mathrm{x} \exists \mathrm{y}$ typos $(\mathrm{y}) \&(\mathrm{x}$ contain $\mathrm{y})]$ ( manuscripts)
$<\mathrm{e}, \mathrm{t}>\rightarrow \mathrm{e}$ TYPE-SHIFT
c. $\exists y$ typos (y) \& ( manuscripts contain y)

The question arises at this point as to what constrains the options for English, which can resort both to "incorporation" and to "nominalization" of property-type arguments. Why is it that the object is composed via existential type-shift of the verb, and the subject via the $\langle e, t>\rightarrow$ e type-shift of the BPL in our example? This is in no way mandatory: though less frequent, the inverse pattern is also attested in examples such as (16a-b), in which the subject is easily interpreted existentially, whereas the object is interpreted generically:

(16) a. High walls surround medieval towns.

b. Powerful computers route modern planes.

Cohen \& Erteschick-Shir (2002) identify information structure as the main factor that determines the possibility of "incorporation". Their answer to our question (ii) above builds on the two following assumptions:

(i) Property-denoting expressions may not be Topics. Therefore, Topic status of a BPL leaves as only repair strategy the $<\mathrm{e}, \mathrm{t}\rangle \rightarrow$ e type-shift.

(ii) Every sentence requires a Topic. The possibility of incorporation/existential typeshift (and thus of existential readings of BPLs) depends on the existence of another argument/adjunct that may function as an (explicit or implicit) Topic (possibly, as in presentational sentences, a Stage-Topic). ${ }^{4}$

Let me illustrate how the combination of both assumptions can account for the fact that (17a) only allows for a generic reading of the subject, whereas (17b-e) are compatible with an existential reading of the subject:
a. [Students]TOP are tall.
b. Criminals own [this club] Tор.
c. Investors are interested [IMPLICIT TOP ARG].
d. Policemen arrived [IMPLICIT STAGE-TOP ARGUMENT].
e. Dogs barked [IMPLICIT STAGE-TOP ADJUNCT].

In (17a), without any further context, the only possible candidate for Topic status is the BPL-subject (there is no further implicit argument, and Stage-Topics are hard to combine with individual level predicates). By assumption (ii), students has to be the Topic, and therefore, by assumption (i), it may not remain at the <e,t>-type. By contrast,

\footnotetext{
${ }^{4}$ In fact, Cohen \& Erteschick-Schir (2002) conceive the link between BPL-interpretations and information structure as a biconditional, so that Focus-status would automatically trigger existential interpretations. The latter assumption lacks the type-theoretical foundation of the first one, and it can be safely ignored for the purposes of the argumentation in this paper.
} 
(17b-e) all offer other possible candidates for Topic status, the object argument in (17b) and different implicit Topics in $(17 \mathrm{c}-\mathrm{e})$. The BPL subjects may thus remain at the $<\mathrm{e}, \mathrm{t}>-$ type, thus triggering the existential type-shift of the verb that accounts for their existential reading.

For reasons of space, I cannot give further examples of their account here. Let me simply state that Cohen \& Erteschick-Shir (2002) convincingly show that manipulating the context by supplying an extra Topic lets emerge existential interpretations of BPLs that look at first sight excluded.

As the proposal sketched in Dobrovie-Sorin \& Laca (1996), Cohen \& ErteschickShir's account has the advantage of capturing the English-Spanish contrast by means of a simple generalization: Spanish lacks the possibility of expressing the $<e, t>\rightarrow$ e- typeshift covertly. It also offers a straightforward explanation for the Naked-NounConstraint banning BPLs as preverbal subjects. In fact, the constraint follows from the combined action of two factors: (i) <e,t>-type expressions cannot be Topics and (ii) Spanish is a free inversion language, in which preverbal subjects (under normal conditions of stress and intonation) are default Topics (see Dobrovie-Sorin \& Laca 2003). If properties cannot be Topics, and Spanish BPLs must remain at the propertydenotation level, it follows that they cannot appear as preverbal subjects. However, the Topicalization constructions introduced in section 1 seem to provide damaging counterevidence to this account.

\section{Topicalized BPLs.}

In a nutshell, the problem is how to reconcile the property-denotation analysis of Spanish BPLs plus the ban on properties as Topics with the existence of topicalized BPLs. The problematic type of example is repeated here for convenience:

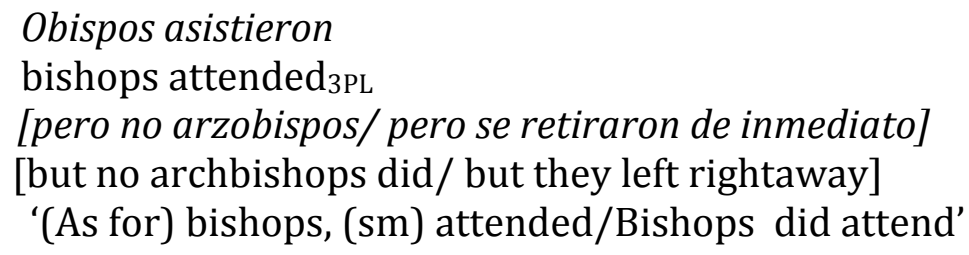

A first preliminary observation is that -at least as far as BPLs are concernedTopicalization works quite differently in English and in Spanish. The contrasting distribution in (19a-d) versus (20a-d) indicates that English topicalized BPLs are generic, kind-referring expressions, whereas Spanish topicalized BPLs have existential import and are property-type.

(19) a. Undergraduates she respected.

b. Undergraduates she meets on Wednesdays.

c. \#Undergraduates she met last Wednesday.

d. *Undergraduates she met several.
a. \#Bachilleres respetaba. undergraduates respected ${ }_{3 \mathrm{SG}}$
b. Bachilleres ve los miércoles.
undergraduates meet $35 \mathrm{~s}$ the Wednesdays 


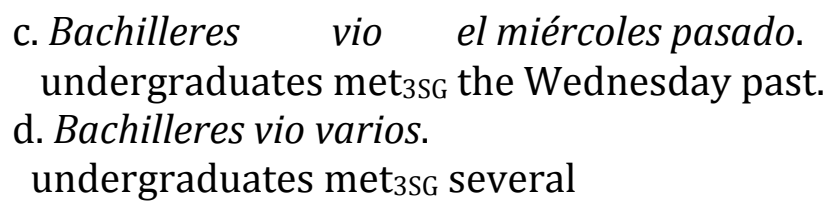

The contrast is particularly clear in (19a) versus (20a), in which the verb is not felicitous with a property-type argument: the fronted Spanish BPL is not acceptable, the English one is perfect. It is also clear in (19d) versus (20d), in which the fronted BPL is associated with a slot (several__) to be filled by a property. In this case, the English BPL is out, whereas the Spanish version is perfect. The episodic context in (19c/20c) makes a kind-denoting interpretation implausible, and the English BPL is correspondingly degraded. The only overlap in the distribution is $(19 \mathrm{~b} / 20 \mathrm{~b})$, in which several factors conspire to produce possibly similar truth conditions, which are nonetheless the result of different derivations. ${ }^{5}$

The claim that property-type expressions may appear in the fronted position in Topicalization is further substantiated by the fact that the nominal element of complex predicates, as in (21a), and bare singular count nouns denoting 'properties of kinds' (Espinal 2010), as in (21b), do appear in analogous structures. These fronted elements are obviously properties.

\section{a. Deporte hace los viernes.}

Sport do3sG the Fridays

'S/he exercices on Fridays'

b. Corbata se pone a veces.

Tie REFL put 3 SG to times

'S/he sometimes puts on a tie'

The fact that Spanish BPLs are always <e,t>-type expressions, even when fronted in Topicalization structures, seems to provide damaging counterevidence to the ban against properties as Topics on which the information-structure account of the distribution of (readings of) BPLs is based. Since the latter assumption works otherwise quite well, the strategy to be followed is that of showing that these fronted elements in Topicalization structures are not Topics, at least not in the sense targeted by the ban against properties as Topics. This strategy has already been suggested by Leonetti (2004), who states that incorporation processes tend to be blocked by internal, but not by external Topic positions.

\subsection{The position of topicalized BPLs.}

The notion of Topic -as most other information structure categories- is known to be used in several different ways. Cohen \&Erteschick-Shir (2002: 131) clearly have aboutness-Topics in mind when formulating the two assumptions on which their account is based. For them, Topics are « the 'address' in the file system under which

\footnotetext{
${ }^{5} \mathrm{I}$ 'm assuming that the derivation of (19b) contains a shifted, kind-denoting undergraduates, whereas that of $(20 \mathrm{~b})$ contains a non-shifted, property-denoting bachilleres. When property-denoting, existential BPLs are backgrounded and interpreted as part of the restrictor in asymmetric event quantification (as is the case in this example), the results become practically indistinguishable from those obtained with kinddenoting BPLs subject to Predicate Transfer in parallel environments (see Cohen 2009 for the mechanism of Predicate Transfer).
} 
sentences are evaluated. That is to say, every sentence expresses some predication over the topic. » Though the notion of aboutness-Topic is intuitively appealing, it is notoriously difficult to develop non-circular criteria in order to distinguish them from other «topical » information structure categories. I will therefore refrain from arguing directly that topicalized BPLs are not " what the associated sentence is about », but follow instead a different line of argumentation. I will try to show that topicalized BPLs do not sit in the normal position for sentence Topics in Spanish, and I will show this by contrasting Topicalization with Clitic Left Dislocation (CLLD).

For the distinction between Topicalization and Left Dislocation, I will stay close to the original characterization of these two types of Fronting (Rivero 1980), which is based on an overt structural difference : while Topicalization involves a gap in a canonical argument position (22a), in Left Dislocation the position associated with the fronted DP/NP is occupied by a pronoun, which in Romance is a clitic pronoun (22b).

a. Un premio le dieron__ a Pablo.

a prize him give ${ }_{3 \mathrm{RDPL}}$ to Pablo.

'It was Pablo who was given a prize'

b. Un premio se lo dieron a Pablo.

a prize him it give 3 RDPL to Pablo

'One of the prizes was given to Pablo'

In the minimal pair constituted by (22a-b), the fronted object is backgrounded, nonfocal. As shown by what I take to be its nearest renderings in English, the indefinite is obligatorily interpreted as specific/partitive/D-linked in the case of Left Dislocation, but not so in Topicalization. (22a-b) also shows that Topicalization is possible with indefinites other than BPLs. But fronted BPLs can only enter into Topicalization structures, a fact that correlates well with the lack of specific/partitive/D-linked readings for BPLs mentioned in section $\$ 2.1$. above.

As for the different structural positions of the fronted constituent in Topicalization and Left-Dislocation, respectively, a number of studies suggest that CLLD in Spanish may involve two different structural positions : an external, peripheral position (possibly at a higher layer of an articulated CP), and a more internal one (at the IP-layer). By contrast, Topicalization does not involve the more internal position. I will assume that it is this more internal position that is dedicated to aboutness-Topics. It is precisely this position that is not available to topicalized BPLs.

It is in principle immaterial for the purposes of our discussion to decide if the more internal position is [SPEC, T] (as in Zubizarreta 1998), or a low adjunction position to Finiteness (as in Haegeman 2006). What is important is that the more external, peripheral position, is only available in clauses having a rich, full or unreduced CP-layer. As convincingly shown by Haegeman (2006), some (but not all) subordinate clauses have a poorer structure than main clauses, a structure she interprets as a reduced CP-layer. This is the case of the adverbial clauses she classifies as central, of subject clauses, and of some object clauses. I am restricting the domain of object-clauses further than she does, by only taking into account the complements of « attitudes of preference » (want-verbs), since there are manifold symptoms of tighter subordination for the latter as compared to other attitude verbs. Now, the contrasts between CLLD and Topicalized BPLs are dramatic in such environments. As shown by examples (23a-b), (24a-b), and (25a-b), CLLD elements are perfectly fine in clauses with a reduced CP- 
layer. If, by hypothesis, such clauses lack the more peripheral position for fronting, this means that CLLD- constituents may sit in the lower Topic position.

Central adverbial clauses

(23) a. Cuando el premio se lo dieron a una película china, hubo un escándalo. When the prize DATCL ACCCL give 3 PL to a movie chinese, had 3 SG $_{\text {a }}$ a scandal 'When the prize went to a Chinese movie, there was a commotion' b. Si los exámenes los pasamos el lunes, tendremos los resultados el miércoles. If the exams AccCL passipL the Monday, have 1PL $_{1 \mathrm{P}}$ the results the Wednesday 'If we take the exams on Monday, we will have the results on Wednesday'

Subject clauses

(24) a. Que el premio se lo vayan a dar a él es un verdadero escándalo. That the prize DATCL ACCCL go3PL to give to him is a true scandal 'It is truly scandalous that he should get the prize'

b. Que los exámenes los pasemos el lunes me parece poco probable. That the exams AcCCL pass 1 PL the Monday me seems little probable 'It looks unlikely to me that we could take the exams on Monday'

Object clauses of "attitudes of preference"

(25) a.Juan pretende que el premio se lo den a él.

Juan pretends that the prize DATCL ACCCL give3PL to him

'Juan pretends to be given the prize'

b. Juan quería que los exámenes los pasáramos el lunes.

'Juan wanted that the exams AcCCL pass 1 SG the Monday

'Juan wanted for us to take the exams on Monday'

In all the above examples, we find a fronted direct object in a case of CLLD inside subordinates clauses with a reduced CP-layer.

By contrast, this position is not available for topicalized BPLs. This is shown by the ungrammaticality of the examples below. These examples parallel those in (23)-(25) but for the fact that the fronted element is a BPL, which is not amenable to CLLD. In each pair of examples we have a fronted BPL object in the (a)-sentence and a "fronted" BPL subject in the (b)-sentence. They behave exactly alike:

a. *Cuando premios dejaron de dar, hubo un escándalo. when prizes left $3 \mathrm{PL}$ of give, had a scandal

Intended meaning: 'When they stopped attributing prizes, there was a commotion'

b. *Si estudiantes no se inscriben, hay que cerrar el curso.

If students not REFL register $3 \mathrm{PL}$, have to close the course Intended meaning: 'If no students register, the course must be cancelled'

(27) a. *Que premios dejen de dar es un verdadero escándalo. that prizes leave $3 \mathrm{PL}$ of give is a true scandal Intended meaning: It is a true scandal that they should stop attributing prizes' b. *Que estudiantes no se inscriban me parece poco probable.

That students not REFL register3PL me seems little probable Intended meaning: 'I don't think it likely that no students will register' 
a. *Juan pretende que novelas dejemos de leer.

Juan pretends that novels leave ${ }_{1 \mathrm{PL}}$ of read

Intended meaning: 'Juan pretends that we should stop reading novels'

b. Juan quiere que estudiantes asistan.

Juan wants that students attend $3 \mathrm{PL}$

Intended meaning: 'Juan wants for (some) students to attend'

From this, we may conclude that topicalized BPLs do not occupy the internal, Tense or Finiteness linked Topic position: they are necessarily more peripheral. Modulo the assumption that aboutness-Topics are structurally lower Topics, this finding rescues Cohen \& Ertschik-Shirs's assumption that properties cannot be Topics from the apparently damaging evidence constituted by topicalized BPLs. Since the assumption concerns aboutness-Topics, the fact that BPLs are indeed excluded from this position actually substantiates the assumption: even so-called topicalized BPLs are excluded from the position occupied by aboutness-Topics. ${ }^{6}$

Notice that we are referring to fronted BPLs as "topicalized" BPLs on the basis of an overt structural property, and have argued that they do not occupy the position of aboutness-Topics. Over and above that (and the fact that they are non-focal), we are not taking any stance as to their information-structure status. The reason is the following: although, as one reviewer accurately points out, most of the examples of fronted BPLs discussed in this paper are highly reminiscent of English as for-topics (but for the fact that English does not allow Indefinite Argument Drop, see below, section §3.2), there are cases where this correspondence breaks down. In such cases, fronting may have the effect of marking a "presupposed open proposition" (Prince 1986) or of forcing VerumFocus (Escandell \& Leonetti 2009). The semantics/pragmatics of Topicalization constructions is an extremely complex issue that cannot even be sketched within the limits of this paper.

From the impossibility of topicalized BPLs in clauses with a reduced CP-layer, we have concluded that they appear in a peripheral Topic position. This brings in a new problem for semantic composition. The peripheral position at the leftmost edge of the main clause is standardly associated with "Hanging Topics". Whereas there is no general consensus on the adequacy of a movement analysis for CLLD, Hanging Topics are generally assumed to be base-generated (Alexiadou 2006). Moreover, a movement analysis for topicalized BPLs is problematic, since they may correlate with a gap in a relative clause island, as shown in (29a-b), and thus violate island-constraints on movement:
a. Puros estoy segura de que no conozco a nadie que fume.
Cigars am sure of that not know 1 sG to nobody that smoke.
'(As for) cigars I'm sure I don't know anybody who smokes them'

\footnotetext{
${ }^{6}$ A reviewer suggests that co-occurrence of BPL-Topicalization with CLLD could strengthen the above argument. Though such cooccurrence is possible, there are two factors that conspire against an argument built on the distributional pattern that emerges. Firstly, whereas the fronted constituent in Topicalization is restricted to the more peripheral position, the fronted constituent in CLLD may occupy any of the two positions. Secondly, the more peripheral position may be multiplied (Kempchinsky 2008). As a result, we obtain both sequences as 'Fronted BPL > Fronted LD DP' and 'Fronted LD DP > Fronted BPL', a finding that can be accounted for by our analysis, but does not provide any new evidence in its favour.
} 
b. Periódicos hay un comerciante en el barrio que vende. newspapers has a shopkeeper in the neighborhood that sells '(As for) newspapers, there is a shopkeeper in the neighborhood who sells them'

Please recall from section $\S 2$ above that sentences containing topicalized BPLs have existential import on the corresponding argument position, and that the mechanism accounting for existential import is the existential type-shift of the verbal predicate. We followed Cohen (2009) in the hypothesis that this mechanism is triggered by the need to solve a type-mismatch when trying to compose the verb with an $<$ e,t $>-$ type argument. Now, if topicalized BPLs have not been moved out of a canonical argument position, they cannot be reconstructed back into that position. Therefore, there should be no step in the composition in which the verb has to compose with the BPL. The question then arises as to what triggers the existential type-shift on the verb that is responsible for existential import in this construction.

\subsection{Topicalized BPLs, Indefinite Argument Drop, and nominal ellipsis.}

I would like to argue that in BPL-Topicalization there is an element of category N/NP and of semantic type <e,t> sitting in the relevant ("gapped") argument position, and that this element triggers the existential type-shift of the verbal predicate. This element is, however, not pronounced. It is not a trace, nor a null-clitic, but a case of N'deletion/NPellipsis, of which there are other instances in Spanish.

The first thing to be noticed is that, while Spanish is not a "Discourse Pro-Drop language",7 it shows some degree of Indefinite Argument Drop (IAD, see Giannakidou \& Merchant 1997, Alexopoulo \& Folli 2010). But IAD can only have a bare nominal as antecedent. This is shown, firstly, by the contrast between (30a), in which it is perfectly fine to drop the object, and (30b), which requires either a clitic or a Det without an overt nominal head.

\section{a. Ando buscando candidatos, pero no encuentro $\varnothing$. walk $_{1 \mathrm{SG}}$ looking-for candidates, but not find $\mathrm{d}_{1 \mathrm{SG}}$ 'I'm looking for applicants, but I don't find them' \\ b. Ando buscando un candidato, *pero no encuentro $\varnothing$. walk $_{1 \mathrm{SG}}$ looking-for a candidate, but not find $\mathrm{d}_{1 \mathrm{SG}}$ \\ pero no lo encuentro/pero no encuentro ninguno. but not ACC.CL find 1 SG $/$ but not find 1 1SG none \\ 'I'm looking for an applicant, but I don't find him/one'}

Secondly, even when the previously mentioned element licensing IAD (i.e. the antecedent) is a weak indefinite DP, the semantic antecedent is only the nominal descriptive content, and not the cardinality information supplied by the Det. As shown by the interpretation of (31), Spanish IAD lacks the "quantificational matching" effect described by Giannakidou \& Merchant for Greek IAD and exemplified in (32):

\section{María trajo diez libros, $\quad$ y Pedro también trajo $\varnothing$. María brought ten books, and Pedro also brought $\varnothing$}

\footnotetext{
7 On the notion of "Discourse Pro-Drop language", see Tomioka (2003).
} 
'María brought ten books, and Pedro also brought books/some books'

I Theodora mazepse deka fraules kai o Andreas pulise $\varnothing$. [GREEK]

the Theodora picked ten strawberries and the Andreas sold $\varnothing$

'Theodora picked ten strawberries and Andreas sold [ten strawberries]'

IAD is also possible for subjects, and is to be distinguished from subject pro-drop, since subject pro-drop requires definite antecedents, as shown in the contrast between (33b) and (33c), whereas subject IAD, as illustrated in (33a), involves a property.

a. ¿Asistieron obispos? - No, no asistieron $\varnothing$.

attended $_{3 \mathrm{PL}}$ bishops? - no not attended $3 \mathrm{PL} \varnothing$

'Did bishops attend? - No, none attended'

b. ¿Asistió el obispo? - No, no asistió.

attended $35 \mathrm{~s}$ the bishop ? - no not attended $35 \mathrm{SG}$

'Did the bishop attend? - No, he didn't'

c. ¿Asistió un/algún obispo ? - No, no asistió *(ninguno).

'Did a/any bishop attend? - No, none attended'

In addition to the lack of quantificational matching effects and to the condition on bareness of the semantic antecedent, Spanish IAD requires a stricter parallelism between the structure containing the antecedent and the one containing the ellipsis than is the case in Greek. As shown in (34a-c) for object drop, identity of subjects or identity of the verb is required in Spanish, but the version in which both subjects and verbs differ is impossible. (34c) requires a clitic, and is ambiguous as to type or token identity.
a. Pedro arregla bicicletas, pero no vende $\varnothing$.
Pedro repairs bicycles but not sell $\varnothing$
'Pedro repairs bicycles, but he doesn't sell them'
b. Pedro arregla bicicletas, y María también arregla $\varnothing$.
Pedro repairs bicycles, and María also repairs $\varnothing$.
'Pedro repairs bicycles, and María repairs them, too.
c. Pedro arreglaba bicicletas y María *(las) vendía.
Pedro repaired bicycles and María (*ACCCL) sold.
'Pedro repaired bicycles and María sold them'

This condition does not apply to Greek (see also (32) above), in which a clitic necessarily produces a token-identity interpretation, leaving IAD as the only option for type-identity (Alexopoulou \& Folli 2010):

a. I Theodora mazepse fraules $k i \quad o$ Andreaspulise [GREEK] the.NOM Theodora picked strawberries and the-NOM Andreas sold

'Theodora picked strawberries and Andreas sold them' ['Disjoint reading', type]

b. I Theodora mazepsefraules ke o Andreastis pulise the.NOM Theodora picked strawberries and the-NOM Andreas Acc.CL. sold

'Theodora picked strawberries and Andreas sold them' ['Non-disjoint', token] 
Thus far, we have established that Spanish can elide nominals in argument position, and that the elided elements are necessarily of category N/NP and of semantic type $<\mathrm{e}, \mathrm{t}>$. To avoid a possible misunderstanding, let me stress that I'm not assuming that Spanish has a "null" clitic corresponding to the partitive clitic en in French (35) which is itself a nominal of semantic type <e,t>. If Spanish had such a null-clitic, (33c) without the accusative clitic would be perfectly fine, which it is not.

$$
\begin{aligned}
& \text { Théodora a cueilli des fraises et Andreas en a vendu. [FRENCH] } \\
& \text { 'Theodora picked strawberries and Andreas sold them' ['Disjoint reading', type] }
\end{aligned}
$$

The same possibility of exhibiting a categorially and type-theoretically uniformly identified gap which we find in IAD is also instantiated in cases of subnominal deletion. In subnominal deletion, a DP or an NP is only represented by a Det (37a), by a Det with a modifier (37b), or by a modifier alone (37c). The elided element is always a nominal projection of semantic type $<\mathrm{e}, \mathrm{t}>$ :

$$
\begin{aligned}
& \text { a. }\left[\text { Muchas }{ }_{\mathrm{FEMPL}} \varnothing\right]_{D P} \quad \text { estaban averiadas } \text { FEMPL }_{\text {. }} \\
& \text { [manyғемPL } \varnothing] \text { were out of order } \\
& \text { b. Quiero }\left[\text { cuatro } \left[\varnothing \text { baratas }_{\text {FEMPL } \left._{\mathrm{NP}}\right]_{\mathrm{DP}}}\right.\right. \\
& \text { want }{ }_{15 G} \text { four cheap }
\end{aligned}
$$

c. Le pedí rosas rojas, pero me trajo $\left[\varnothing \underline{\text { amarillas }}\right.$ FeMPL $_{\mathrm{NP}}$

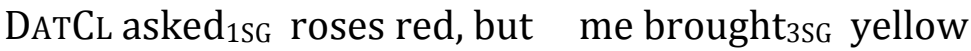

'I asked him for red roses, but he brought me (some) yellow ones'

Having thus established that null-arguments licensed by an anaphoric link in Spanish have a uniform categorial (N'/NP) and type-theoretical $(<e, t>)$ identity, which exactly matches the identity of the elements subject to subnominal deletion, we can go back to the question stated at the end of the previous section: what triggers the existential type-shift of the verb, which is required for deriving the existential import of topicalized BPL, if the BPL has not been moved out of its canonical argument position and cannot therefore be a possible candidate for composition with the verb at any stage of the composition?

There are two possible answers to this question. The first is to assume that Topicalization involves an instance of argument ellipsis. Any of the two concurring approaches to ellipsis -recycling of the descriptive content of the antecedent by LFcopying, or PF-deletion- would have the same effect of providing a BPL at the stage where it is needed for semantic composition:

\section{a. Novelas [ leo novelas] LF-copying \\ b. Novelas [leo novelas] PF-deletion}

The obvious problem for this solution is the fact that the non-elliptical structure (as in a pronounced sequence (38a)) is not felicitous. It is, however, not clear to me whether this infelicity has a grammatical source, or rather an informational one.

The second answer is simply that, since an empty argument position which is neither pro nor $P R O$ has a uniform semantic type, $<\mathrm{e}, \mathrm{t}>$, this is enough for triggering existential type-shift of the verb as a repair strategy for the type mismatch at the proper stage of composition. This is shown schematically in (39): 

a. Novelas $_{i}\left[\right.$ leo $\left._{1 \mathrm{stsg}} \varnothing_{i}\right]$
b. $[\lambda \mathrm{y} \lambda \mathrm{x}(\mathrm{x} R E A D \mathrm{y})](\varnothing)$
TYPE MISMATCH
c. SHIFT $(R E A D)=\lambda \mathrm{P} . \lambda \mathrm{x}$. $\exists \mathrm{y}(\mathrm{P}(\mathrm{y}) \& \mathrm{x} R E A D \mathrm{y})$
EXISTENTIAL TYPE-SHIFT
d. [novels $\mathrm{s}_{\mathrm{i}}$ ] $\mathrm{y} \varnothing_{\mathrm{i}}(\mathrm{y}) \&$ (Speaker READ y)

Notice that coindexation is used here to indicate nothing more - nor less - specific than identical denotation for both coindexed elements: the semantic value of $\varnothing$ is identical to the semantic value of the topicalized BPL. (39a) shows that the verb has first to compose with a "gap" in its internal argument position. Since this gap is necessarily of $<e, t>$-type, we obtain a type mismatch in (39b). And this type mismatch triggers the shifted version of the verb that is needed for ensuring the existential import of these sentences, as given in (39c). After composition with the $1^{\text {st }}$ person subject, we obtain something akin to (39d). I'm painfully aware of the fact that the syntactic status of $\varnothing$ is theoretically blurry. An anonymous reviewer suggests to treat $\varnothing$ (the empty nominal predicate) as a free variable ranging over properties, with the topicalized BPL affecting (or rather fully determining) the assignment function in the interpretation of this variable. Although this line of analysis seems promising, it would lead us to assume a kind of free variable that has to be identified by a close linguistic antecedent of the right category and semantic type (the topicalized BPL in this construction, a nominal in a previous utterance in cases of IAD or subnominal deletion). I cannot evaluate at present the consequences of introducing such an object.

Let me simply add that the options illustrated for the object in (38) and (39) also extend to Topicalized BPL-subjects. In such cases -which are also possible with inergatives, provided that there is another aboutness-Topic candidate, such as the locative in (40a) or an implicit Argument/Stage-Topic in (40b)- neither the BPL nor the $\varnothing$ element is sitting in the lower, internal Topic position.

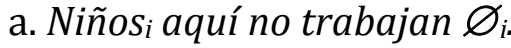 \\ children here not work ${ }_{3 \mathrm{PL}}$ \\ 'As for children, none work here'

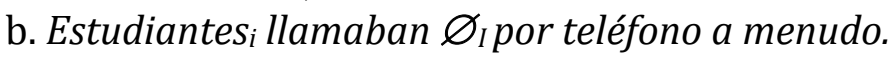 \\ students called $3 \mathrm{PL}$ by phone often \\ 'Students often phoned'
}

\title{
3.3. Split topicalization
}

There is a second construction involving a "fronted", non-focussed BPL, which could be amenable to the same type of analysis as BPL-Topicalization, so-called Split-NPTopicalization (SNPT, see Hoof 2006, Puig Waldmüller 2006) . As illustrated in (41), in SNPT a fronted nominal constituent ('тоРІC') enters an anaphoric relation with a nominal gap contained in a 'REMNANT' DP/NP.

Obispos $_{i}$ asistieron varios $\varnothing_{i \text {. }}$

bishops attended ${ }_{\mathrm{PL}}$ several
'TOPIC'
'REMNANT'

The 'TOPIC' is always a bare NP - including NPs without a nominal head represented by an adjective or a prepositional adjunct, as in (42): 
(42) Le di una toalla usada, porque $\left[\varnothing_{i} \text { limpias }\right]_{N / N P}$ quedaban [muy pocas $\varnothing_{i}$ ]. DATCL gave $_{1 S G}$ a towel used, because clean remained ${ }_{3 \mathrm{PL}}$ very few 'I gave him/her a used towel, because we had very few clean ones left'

The 'REMNANT' is by an large an NP/DP containing a nominal gap of type <e,t>:
a. Zapatillasinos quedan solo [ $\varnothing_{i}$ de plástico]/[(unas) [ $\varnothing_{i}$ verdes]. slippers us remain 3 PL only of plastic / (UNAS) green 'Slippers we only have plastic ones left / some/a pair of green ones left'
b. Zapatillasite daré [todaslas $\varnothing_{i}$ que quieras]. slippers you $_{\text {DAT }}$ give $_{1 S G}$ all the that want 2 SG 'Slippers I'll give you as many as you want'
c. Zapatillasite puedo dar [éstas $\varnothing_{i}$ ] slippers you DAT $_{\text {Can }}$ ISG $_{1}$ give these 'Slippers I can give you these ones'

SNPT exhibits even more paradoxes for a movement analysis than BPLTopicalization does. As shown in the following examples, reconstruction of the BPL into the 'REMNANT' may produce ungrammatical sequences, for instance when there is a mismatch between the number features of the BPL and those of the 'REMNANT'(44a-b) , or when the BPL is modified by a subjunctive relative clause and the 'REMNANT' does not contain an operator that may license a subjunctive relative (45a-b), :

\section{a. Libroste puedo darsolo [uno $\varnothing /$ éste $\varnothing]$.} books you ${ }_{\mathrm{DAT}} \mathrm{can}_{1 \mathrm{SG}}$ give only [one $\varnothing /$ this $\varnothing$ ]. 'As for books, I can give you only one/this one'

b. Te puedo dar solo *[un(o) libros/este libros]. you $_{\mathrm{DAT}} \mathrm{can}_{1 \mathrm{SG}}$ give only*[one books /this books] *'I can give you only one books/this books'

\section{a. Librosque me interesaran leí [varios $\varnothing]$.}

Books that me 1 SG-ACC interest 3 PL-SBJ read $_{1 \mathrm{SG}}$ [several $\varnothing$ ] 'As for books that could interest me, I read several ones'
b. Leí [varios libros que me
*interesaran/ interesaron.]
$\operatorname{read}_{1 \mathrm{SG}}$ [several books that me 1 SG-ACC interest $_{3 \mathrm{PL}-\mathrm{SBJ}} /$ interest $_{3 \mathrm{PL}-\mathrm{IND}}$ ]
'I read several books that interested me'

A movement solution is even more implausible when the 'REMNANT' is a full DP, lacking a nominal gap, whose referent must be in a member-set relationship with the 'TOPIC':

$$
\begin{aligned}
& \text { Novelas escribió solo "Le diable" y "Le bal". } \\
& \text { novels wrote } 3 \text { SG only "Le diable" and "Le bal" } \\
& \text { 'The only novels he wrote are "Le diable" and "Le bal"' }
\end{aligned}
$$

In the light of structures such as (46), a uniform analysis for Topicalization and SNPT should favor the second solution sketched at the end of the previous section. "Fronted" property-denoting expressions are licensed if they establish an anaphoric link with an element in the associated sentence. This anaphoric link amounts to identity 
when the element in question is the categorially and type-theoretically determined $\varnothing$ element that also appears in IAD and in subnominal deletion. It is a member-set-link when the element in question is referential.

A uniform analysis for Topicalization and SNTP seems intuitively desirable. Firstly, the same peculiar intonational contour, with a high rise in the first intonational unit, characterizes both structures. Secondly, the information structure effects of both constructions are parallel. One of these effects is that of backgrounding the BPL, preventing it from occurring in a position in which it would be (part of) the Focus. This may have as a result Verum-Focus sequences, in which the focussed element can only be the (positive or negative) polarity of the associated sentence (cf. 47) . Nonetheless, these structures are intonationally, structurally, and informationally different from the specific phenomenon of Verum Focus Fronting described by Escandell \& Leonetti (2009). In fact, as shown by Leonetti (2009), BPLs are excluded from Verum Focus Fronting in the absence of special conditions (cf. 48):

A: ¿Qué pasa? ¿No vienen más turistas?

'What's the matter? Have tourists stopped coming?'

B: Turistas vienen, pero no gastan nada.

Tourists come, but not spend nothing

'Tourists do come, but they spend nothing'

\footnotetext{
Películas *(mejores) he visto.

Movies * (better) have 1 sG seen

'I've seen better movies'
}

Whereas backgrounding of discourse-given material seems common to all instances of Topicalization, including SNPT, it is less clear that the phenomenon lives up to its label, and thus necessarily involves informational elements that are in some sense Topics.

\section{Conclusion}

In this paper, I have shown that the existence of "topicalized" BPLs poses serious problems for the analysis of Spanish BPLs as property-type expressions that are bound to compose via a mechanism akin to incorporation. The first problem is that the very existence of "topicalized" BPLs casts doubt either on the assumption that Spanish BPLs are always property denoting, or on the the assumption that properties may not be Topics. A comparison with BPL-topicalization cases in English indicates that, even when fronted, Spanish BPLs end up having existential import. A comparison with CLLD shows that "topicalized" BPLs are not sitting in the position of internal Topics. We thus conclude that the ban against property denotations holds for internal Topics, but not for external Topics, which are not the aboutness-Topics targeted in Cohen \& ErteschickShir's generalizations. Whereas this salvages an information-structure based account for the Naked Noun Constraint, it poses a problem of composition. Since external Topics do not seem to land at their fronted position via movement from an argument position, but to be base-generated, the question arises as to what triggers the existential type-shift of the verb in the associated sentence. We have explored the possibility that the associated sentence contains a $\varnothing$ element standing in an anaphoric link to the fronted BPL. This $\varnothing$ element is categorially specified as N'/NP and type-theoretically specified as $<\mathrm{e}, \mathrm{t}\rangle$, as can be shown by the -to my knowledge hitherto unnoticed- phenomenon of IAD in 
Spanish, and by the much better known phenomenon of subnominal deletion. The categorial and type-theoretical specification of $\varnothing$ would thus suffice to trigger the required existential type-shift. The material discussed in this paper suggests that further research is necessary on two different issues: (i) the precise relationship between IAD and subnominal deletion in Spanish, and (ii) the actual informational and discoursefunctional role of topicalized BPLs. 


\section{References}

Abeillé, Anne. 2006. In defense of lexical coordination. In : O. Bonami \& P. Cabredo-Hofherr, eds. Empirical issues in syntax and semantics 6, 17-36. http:// www.cssp.cnrs.fr/eiss6

Alexiadou, Artemis 2006. Left dislocation (including CLLD). In: M. Everaert \& H. v. Riemsdijk (ed). The Blackwell companion to syntax. Vol. II. Oxford. Blackwell.

Alexopoulo, Teodora. \& Folli, Raffaella. (2010) Indefinite topics and the syntax of nominals in Italian and Greek. https://sites.google.com/site/wccfl28pro/alexopoulou-folli

Carlson, G.N. 1977. Reference to kinds in English. PhD Dissertation, Amherst..

Chierchia, G. 1998. Reference to kinds accross languages. Natural Language Semantics 6.

Cohen, Ariel. 2007. The information structure of Bare Plurals in English and Italian. In : K. Schwabe \& S. Winkler (eds), On information structure, meaning, and form. Amsterdam. Benjamins.

Cohen, Ariel. 2009. No quantification without reinterpretation. Talk given at the 1st GENIUS International Conference. Paris.

Cohen, Ariel \& Erteschik-Shir, Nomi. 2002. Topic, Focus and the Interpretation of Bare Plurals. Natural Language Semantics 10, 125-165.

Condoravdi, Cleo. 1994. Descriptions in context. PhD Diss. Yale University.

Contreras, Heles. 1996. Sobre la distribución de los sintagmas nominales no predicativos sin determinantes. In : Bosque, I. (ed) El sustantivo sin determinación. La ausencia de determinante en la lengua española. Madrid. Visor.

Dobrovie-Sorin, Carmen. \& Laca, Brenda. 1996. Generic BNPs. Ms. Université Paris 7/ Université Strasbourg II.

Dobrovie-Sorin, Carmen \& Laca, Brenda. 1998. La généricité entre la référence à l'espèce et la quantification générique. In: P. Sauzet (ed) Actes du colloque Langues \& Grammaire 3. St Denis. Université Paris 8.

Dobrovie-Sorin, Carmen \& Laca, Brenda. 2003, Les noms sans déterminants dans les langues romanes, in Godard, D. (ed). Les langues romanes. Problèmes de la phrase simple. Paris. CNRS Editions.

Escandell Vidal, Victoria \& Leonetti, Manuel. 2009. Fronting and Verum-focus in Spanish. In: A. Dufter \& D. Jacob (eds). Focus and background in Romance languages. Amsterdam, Benjamins. 155-204.

Espinal, Maria Teresa 2010. Bare Nominals in Catalan and Spanish. Their structure and meaning. Lingua 120.

Geenhoven, Merle van 1996. Semantic incorporation and indefinite descriptions. PhD. University of Tübingen.

Giannakidou, Anastasia \& Merchant, Jason 1997. On the interpretation of null indefinite objects in Greek. Studies in Greek Linguistics 17. 141-155. Aristotle University, Thessaloniki.

Hoof, Hanneke van. 2006. Split Topicalization. In: M. Everaert \& H. v. Riemsdijk (ed). The Blackwell companion to syntax. Vol. II. Oxford. Blackwell

Kempchinsky, Paula. 2008. How Much Structure Does the Left Periphery Need? Poster presented at the Linguistic Symposium on Romance Languages 38, University of Illinois-Urbana Champaign.

Haegeman, Lilian. 2004. Topicalization, CLLD, and the left periphery. http://www.zas.gwzberlin.de/fileadmin/material/.../zaspil35-haegeman.pdf

Krifka, Manfred. 2004. Bare NPs: Kind-referring, Indefinites, Both, or Neither ? O, Bonami \& P. CabredoHofherr (eds) Empirical Issues in Formal Syntax and Semantics 5. Pp. 11-132. http://www.cssp.cnrs.fr/eiss5.

Krifka, Manfred \& al. 1995. Genericity: an introduction, in Carlson et al. (ed) The Generic Book. The University of Chicago Press.

Laca, Brenda. 1996. Acerca de la semántica de los plurales escuetos en español. In : Bosque, I. (ed) El sustantivo sin determinación. La ausencia de determinante en la lengua española. Madrid. Visor

Laca, Brenda. 1999. Presencia y ausencia de determinantes. In : Bosque, I./Demonte, V. (ed.) Nueva gramática descriptiva de la lengua española. Madrid. Espasa Calpe. .

Leonetti, Manuel. 2004. Specificity and differential object marking in Spanish. Catalan Journal of Linguistics Vol. 3.

Leonetti, Manuel. 2009. Remarks on Focus Structure and Non-Specificity. In: M.T. Espinal et al. (eds.), Proceedings of the IV Nereus International Workshop "Definiteness and DP Structure in Romance Languages". Arbeitspapier 12. Fachbereich Sprachwissenschaft, Universität Konstanz.

McNally, Louise. 1995/2004. Bare plurals in Spanish are interpreted as properties. Catalan Journal of Linguistics Vol. 3. 
Prince, Ellen F. 1986. On the Syntactic Marking of Presupposed Open Propositions. Proceedings of the 22nd Annual Meeting of the Chicago Linguistic Society. 208-222.

Puig Waldmüller, Estela. 2006. Wörter stehen da einige. On nominal split topicalization in non-standard Viennese German. Barcelona. Universitat Pompeu Fabra. Final research paper.

Real Academia Española. 2009. Nueva gramática de la lengua española. Madrid. Espasa.

Rivero, María Luisa. 1980. On Left-Dislocation and Topicalization in Spanish. Linguistic Inquiry 1, 2.

Suñer, Margarita. 1982. The Syntax and Semantics of Spanish Presentational Sentence-Types. Washington..C. Georgetown University Press.

Tomioka, Satoshi. 2003. The semantics of null arguments in Japanese and its cross-linguistic implications. Schwabe, K \& S Winkler (eds.), Interfaces, Amsterdam. Benjamins. 321-339.

Zubizarreta, Maria Luisa. 1998. Prosody, Focus and Word Order. Cambridge. MIT Press 